\title{
The Impact of Women Entrepreneurship Development: Case Study of VIDATHA Programme, Sri Lanka
}

\author{
Dambugolla D.W.C.P. \\ Research Officer, Ministry of Foreign Affairs, Sri Lanka
}

\begin{abstract}
Every aspect of the world is changing rapidly; political and economic transformations seem to arise every nock and corner in the world. Countries tend to demand their economies; dictatorships convert into democracy while creating new institutions and agencies. Due to the changes in economic pathways for women, those who intend to start and operate their own businesses. When women gradually start their own businesses with a view to contribute a large portion in the national economy, the unique skills of women entrepreneurs are yet to recognize. In this context, this research examined women's entrepreneurial characteristics in Sri Lanka mainly based on environmental factors. The case study focused on the VIDATHA program which initiated by the Ministry of Science, Technology and Research in mid-2000. This study aimed to investigate the effect of environmental factors on women entrepreneurial characteristics in Western Province, Sri Lanka. The result of this analytical study indicated that there are similarities and differences in experiences of women entrepreneurs in Sri Lanka and women entrepreneurs were able to run their businesses and reached successes, despite the work-family conflicts. The outcome of the women's engagement in business proved that the support for service of the companies and competitiveness is significantly correlated with the environmental factor which the main source for the availability of funding for development of women entrepreneurship. The factors influence women to be at risks of businesses could easily be improved through the activities of business support services, followed by independence, selfconfidence and internal locus of control. The business support service is the main factor influenced the development of female entrepreneurship. Competitiveness and government policies were given a negative impact on developments of women entrepreneurship.
\end{abstract}

KEYWORDS: Women Entrepreneurs, Entrepreneurial traits, Entrepreneurial Environmental Factors 


\section{INTRODUCTION}

More women now participate in paid employment than at any other time in history across all geographical regions (Heintz, 2006) and therefore, the emergence of women entrepreneurship in the past two decades is not a coincidence (Hisrich and Brush, 2006). The entire business environment has changed and women are being encouraged to participate in various business activities a process that was unimaginable decades ago (Pink, 2004).

Women-owned businesses are growing rapidly all over the world. While no exact data are available on the number of women entrepreneurs (Stevenson, 1990), today, women in advanced market economies own more than $25 \%$ of all businesses (Bhatt, 1991) and womenowned businesses in South Asia are growing rapidly (Bodrova, 1993), and in Sri Lanka (Moonasinghe, 2000). Entrepreneurship offers tremendous opportunities for women by opening doors to greater self-sufficiency, selfesteem, education, and growth, not only for the women themselves but also for their families and their employees (Estes, 1999). While there are constraints and lack of support for women entrepreneurs to conduct business (Staseson, 2001), many women are doing so regardless, and are doing so successfully (Blacklock, 2000).

It has been found that women business operators in Sri Lanka have been mostly concentrated in three subsectors that have been extensions of the skills utilized at their homes; food processing, garments, and handicrafts and there is very little indication that majority of such women had been able to upscale their activities even within these sub-sectors or that they have been able to expand into other sub- sectors through diversification

(Kodithuwakku and Perera, 2003). Another tradition that has greatly contributed to the emergence of women entrepreneurship is the intensive involvement of women in family-owned businesses (Jayaweera, 1996). Recent developments indicate that women diversify into non-traditional sectors, which are more service-oriented (Bird and Brush, 2002). However, women-owned businesses are becoming more important in less traditional sectors like transportation, communication, finance, insurance and real estate (Gosselin and Grise, 2004).

The number of Women Entrepreneurs and Women Decision-makers in an economy is an important indicator of gender-related policies. In Sri Lanka, 25 percent of the establishments are run by women entrepreneurs or decision makers, while its percentage in the rural areas (35 percent) is significantly higher than that of the urban areas (28percent). The Listing of the Economic Census also reports that the country's economy comprises of around 1.02 million establishments of which 71,126 small scale establishments and 10,405 are medium scale establishments. (Economic Census 2013/2014) 
Table 1: Number of Industry establishment - 2013-2014

\begin{tabular}{|c|c|c|c|c|c|}
\hline & \multicolumn{4}{|c|}{ No. of Establishments } & \multirow{2}{*}{$\begin{array}{l}\text { Persons } \\
\text { Engaged }\end{array}$} \\
\hline & Total & $\%$ Registered & $\begin{array}{c}\% \text { Run by } \\
\text { Females }\end{array}$ & $\begin{array}{c}\% \text { With Sole } \\
\text { Ownership }\end{array}$ & \\
\hline Total & $1,019,681$ & 57.6 & 24.8 & 90.4 & $3,003,119$ \\
\hline Micro & 935,736 & 54.6 & 26.3 & 93.1 & $1,338,675$ \\
\hline Small & 71,126 & 89.1 & 8.3 & 64.5 & 529,751 \\
\hline Medium & 10,405 & 100.0 & 6.1 & 35.9 & 386,756 \\
\hline Large & 2,414 & 100.0 & 4.6 & 20.3 & 747,937 \\
\hline
\end{tabular}

(Department of Census and Statistics, 2013/2014)

\section{Characteristics of Women Entrepreneurs}

Women in entrepreneurship possess dual characteristics (for instance, they are firstly women and secondly entrepreneurs). Therefore, women entrepreneurs possess characteristics which include adaptability (Kilby, 1968), innovativeness/creativity (Schumpeter, 1934. Drucker,1985), strength and internal locus of control (Annenkova, 2001), ability to think and reason fast and endure (Mayoux, 2001), managerial skill, accountability and credit risk (Thomson, 2002). Factors that motivate women entrepreneurs have been identified to include, dissatisfaction with "glass ceiling" (Farniloni, 2007) or limits on their earnings and advancement (Stoner and Fry,1982), need to improve quality of life (Cooper, 1983), desire to earn more income, growth and innovation (Carland et.al 1984), desire for independence, risktaking propensity (Brockhaus, 1980), education, freedom, job flexibility and previous experience (Mansor, 2005).

\section{Women Entrepreneurial Development and Environmental Factors}

Development connotes a human multifarious and divergent process, manifested in every field of endeavor, which entails the overall improvement of man and his well being, to the level of the social group which involves an increased capacity to regulate both internal and external relations (Rodney, 1976). On the other hand, the environment is the interrelated and interdependent variables or forces which affect the ways business operates. The business environment is highly dynamic and hence controls the operations and activities of business ventures. The understanding of the dynamism and the effect of environment on women entrepreneurial development is very important for policy making. Kantor (1999) and Iheduru (2002) saw family influence as the antecedent of women entrepreneurial development. Ronstadt (1984), Morris and Lewis ( 1991) and lLO (1998) included infrastructure, legal, regulatory, economic and socio-cultural variables such as rapid and threatening change, one's family, school and work environment as the environmental factors that can affect women entrepreneurs. 
Watkins and Watkins (1986) further classified these factors into 'push' and 'pull' factors. Keeble and Walker (1994) looked at the environmental factors from the perspective of the developmental setting that stimulates local market. Several environmental indicators have been identified as the major factors that can either hinder or inhibit women entrepreneurs. Minniti and Arenius (2003) argue that these factors are the supportive services that enhance women entrepreneurial development. ILO (2003) regards environment factors as the external factors that include: (i) government policy (fiscal and legislative framework), (ii) access to appropriate business development support, (iii) access to finance and financial services and (iv) community and family. Mansor (2005) enumerated these factors, namely: venture capital availability, the presence of experience, technically skilled labour force, accessibility of suppliers, customers, new markets, government influences, land, transportation, new technological development, supporting services and living condition.

\section{The VIDATHA Programme}

The VIDATHA concept (technology to village - Gamata Thakshanaya) program was initiated during mid-2000 to enhance the rural economy. It was a timely needed mechanism to transfer locally developed technologies to potential small and medium scale entrepreneurs among the rural folk in Sri Lanka. Therefore the VIDATHA is an indigenous term for the Transfer of Science and Technology. (VI - Vidyawa; Da- Dana; Tha- Takshanaya) The Vision of the VIDATHA Program is "utilization of the full potential of Science and Technology (S\&T) to improve the living standards of Sri Lankans, giving priority to the village which hitherto has not attracted attention". The core objective of the VIDATHA program is "to transfer scientific and technological know-how of locally developed simple technologies - both industrial and agricultural - to rural people through various programs and thereby develop small and medium scale entrepreneurs in the rural sector with a view to uplift the living standards of rural people while eradicating poverty and reducing unemployment".

The VIDATHA program was officially launched in 2005 with the approval of the Cabinet of Ministers. It was announced in the Budget Speech of 2005 and it was envisaged to establish a VRC in each Divisional Secretariat, to function as a focal point of transfer of technologies to villages. It was expected to transfer primary technologies free of charge, secondary technologies for a concessionary rate while tertiary technologies for a fair price.

In order to achieve the objectives of the VIDATHA Program, 307 science graduates were recruited as Science \& Technology Officers (STO) to give leadership in transferring technologies at village levels under the close supervision of the Divisional Secretary of the area. The STO is assisted by a Field Coordinator, a Computer Operator and an Office Assistant (Peon) in the delivery of functions of a VRC. In addition, another 27 graduates were recruited as Technology and Human Resource Promotional Assistants and they are supposed to help entrepreneurs in packaging and marketing aspects. The VRCs maintain computer databases of ready-to-transfer technologies, natural resources in the Divisional Secretarial divisions, lists of entrepreneurs they developed and other existing 
entrepreneurs in Divisional Secretarial divisions. Besides, CDs, brochures and leaflets about available technologies are kept there for public information. The VRCs are also provided with some equipment such as a bakery oven, dehydrator, virgin coconut oil extractor, yogurt incubator and computers for training and providing information to village people.

Therefore, this study is aimed to investigate the effect of environmental factors on women entrepreneurial characteristics in Western Province, Sri Lanka. To achieve this objective, the following research questions will be addressed: How those environmental factors affect women entrepreneurship development? How these factors affect to development of women entrepreneurship in developing countries? Is there any relationship between environmental factors and women entrepreneur's traits? Answers to the above questions, this paper is ordered as literature review, conceptual framework and an explanation of the research methods, report and discussion of findings and summary, conclusions, policy suggestions, and future research.

\section{METHODOLOGY}

The aim of the study is to discuss and analyze the effects of different factors (mentioned below) to become a women entrepreneur. The structured questionnaire was designed for this purpose to collect the qualitative data. The data consists of a survey carried out among women entrepreneurs in VIDATHA program, Ministry of Science Technology and Research in 2015. The questionnaire has two sections: Section A consists on queries on the demographic data of the respondents (Age distribution, marital status, nature of the business, educational background), Section B is on the effect of environmental factors to become as an entrepreneur, women entrepreneurial traits and women entrepreneurship development through technology transfer.

To identify the relationship between entrepreneurial traits and environmental factors in terms of Women Entrepreneurship Development a regression model developed as follows. $\mathrm{Yi}+\mathrm{a}+\mathrm{b} 1 \mathrm{X} 1 \mathrm{i}+\mathrm{b} 2 \mathrm{X} 2 \mathrm{i}+$ ................... bnXni,

Where:

$\mathrm{Y}=$ Women Entrepreneurship Development

$\mathrm{a}=$ Constant

$\mathrm{b}=$ Slope

$\mathrm{X} 1=$ Accessibility to Financing

$\mathrm{X} 2=$ Support Service

$\mathrm{X} 3=$ Family conflict

$\mathrm{X} 4=$ Competiveness

$\mathrm{X} 5 \quad=\quad$ Government Policy

Accordingly, the following hypothesis were formulated H1: Women Entrepreneurial traits are strongly influenced by environmental factors

H2: There is a significant relationship between environmental factors and women entrepreneurship development through technology transfer

\subsection{Population, Sample Selection and Data Collection}

This study was conducted among the registered women business operators of the VIDATHA program (conducting by the Ministry of Science, Technology and Research) of the Nine Provinces in 2015. A list of registered women business operators was obtained from the VIDATHA Program; a total of 125 
questionnaires were distributed and received only 118 (94.4\% received). Women business operators were members of the program under five different types of businesses. Simple Random Sample was stratified based on industry and the probability proportionate to size. Fifty two percent (52\%) of the population is covered in the sample and the respective women business operators were drawn at a fixed interval basis within the strata that amount to a sample of 59 women business operators.

Table 2: Population \& Sample selection

\begin{tabular}{|c|l|c|c|}
\hline & Industry Sector & Population Size & $\begin{array}{c}\text { Sample } \\
\text { Size }\end{array}$ \\
\hline 1 & Agro Based Products & 14 & 7 \\
\hline 2 & Food-Based Products & 16 & 8 \\
\hline 3 & Garment and Tailoring & 56 & 28 \\
\hline 4 & Leather \& Rexene Based Products & 20 & 10 \\
\hline 5 & Other & 12 & 6 \\
\hline & TOTAL & $\mathbf{1 1 8}$ & $\mathbf{5 9}$ \\
\hline
\end{tabular}

Sources: Annual Report, Ministry of Science, Technology and Research, 2015

\section{RESULT}

\section{Demographic Variables}

This paper focuses on the impact of the environment created by VIDATHA program on Sri Lankan women entrepreneurs. The first task is to discuss the demography of Sri Lankan women entrepreneurs (Table 3). According to the survey results of this study, results show that $74.5 \%$ women entrepreneur's ages between 20-50 and married whereas $67.8 \%$ were married and $32.2 \%$ were unmarried. Also, they had children ranging 1 to 4 . Women entrepreneurs in this study engaged in Agro-based products - $11.9 \%$, Food-based products 13.6\%, Garment and Tailoring - 47.5\%, Leather and Rexene based products $16.9 \%$ and other $-10.2 \%$. The education level of the women entrepreneurs were $33.9 \%$ passed GCE $(\mathrm{A} / \mathrm{L})$ which is highest. Second highest is Technical education - 23.7\%, Seminar/Workshops 16.9\%, GCE (O/L) - 15.3\% and By Experience $-10.2 \%$.

Table 3: Demographic factors of Women Entrepreneurs

\begin{tabular}{|l|l|l|l|}
\hline \multirow{2}{*}{ Variables } & Items & Total & Percentage \\
\hline \multirow{4}{*}{ Age } & $20-30$ & 11 & $18.6 \%$ \\
\cline { 2 - 4 } & $31-40$ & 22 & $37.3 \%$ \\
\cline { 2 - 4 } & $41-50$ & 11 & $18.6 \%$ \\
\cline { 2 - 4 } & $51-60$ & 9 & $15.3 \%$ \\
\cline { 2 - 4 } & Above 61 & 6 & $10.2 \%$ \\
\hline
\end{tabular}




\begin{tabular}{|c|c|c|c|}
\hline \multirow{5}{*}{$\begin{array}{l}\text { Education } \\
\text { Level }\end{array}$} & GCE (O/L) & 9 & $15.3 \%$ \\
\hline & GCE (A/L) & 20 & $33.9 \%$ \\
\hline & Technical & 14 & $23.7 \%$ \\
\hline & By Experience & 6 & $10.2 \%$ \\
\hline & Seminars/ Workshops & 10 & $16.9 \%$ \\
\hline \multirow{5}{*}{$\begin{array}{l}\text { Type of } \\
\text { Business }\end{array}$} & Agro Based Products & 7 & $11.9 \%$ \\
\hline & Food-Based Products & 8 & $13.6 \%$ \\
\hline & Garment and Tailoring & 28 & $47.5 \%$ \\
\hline & $\begin{array}{l}\text { Leather and Rexene Based } \\
\text { Products }\end{array}$ & 10 & $16.9 \%$ \\
\hline & Other & 6 & $10.2 \%$ \\
\hline \multirow{5}{*}{$\begin{array}{l}\text { No of } \\
\text { Children }\end{array}$} & 0 & 19 & $32.2 \%$ \\
\hline & 1 & 2 & $3.4 \%$ \\
\hline & 2 & 23 & $39.0 \%$ \\
\hline & 3 & 12 & $20.3 \%$ \\
\hline & 4 & 3 & $5.1 \%$ \\
\hline
\end{tabular}

Source: Field Survey 2015

\section{Environmental Factors and Entrepreneurial Traits}

Mean of the independent and dependent variables were calculated to test the hypothesis. (Table 4). According to the 5point Likert scale model, items with a mean score of three and above can be used to be in concordance with the position of the questions in the questionnaire. Values below three indicated a need for development in the respective areas of Women Entrepreneurship Development. Values higher than three represent a positive impact on women entrepreneurship. According to the results of this study accept internal locus of control and women entrepreneurs' strength and energy, other traits need for development.

Table 4: Descriptive Statistics

\begin{tabular}{|l|c|c|}
\hline & Mean & Std. Deviation \\
\hline Risk Taking & 2.34 & 1.347 \\
\hline Inter Locus of Control & 3.47 & 1.443 \\
\hline Tolerance For Ambiguity & 2.17 & 1.162 \\
\hline Strength And Energy & 3.44 & 1.303 \\
\hline Creative And Innovative & 2.51 & 1.305 \\
\hline Independence & 2.15 & 1.201 \\
\hline Self Esteem & 2.25 & 1.308 \\
\hline Self Confidence & 2.32 & 1.319 \\
\hline Competitiveness & 2.66 & 1.268 \\
\hline Pro-activeness & 2.10 & 1.062 \\
\hline Self Achievement & 2.64 & 1.256 \\
\hline
\end{tabular}




\begin{tabular}{|l|c|c|}
\hline Accessibility to Financing & 1.88 & 1.115 \\
\hline Support Service & 2.24 & 1.291 \\
\hline Family support & 1.93 & 1.112 \\
\hline Competitiveness & 1.78 & .984 \\
\hline Government Policy & 2.15 & 1.337 \\
\hline
\end{tabular}

Source: Field survey 2015.

\section{Correlation Analysis}

Correlation was examined between the entrepreneurial traits of women entrepreneurs and environmental factors through correlation analysis. Correlation matrix is given in the following table.

Table 5: Correlations between Entrepreneurial Traits and Environmental Factors

\begin{tabular}{|l|c|c|c|c|c|}
\hline & $\begin{array}{c}\text { Accessibility } \\
\text { To Financing }\end{array}$ & $\begin{array}{c}\text { Support } \\
\text { Service }\end{array}$ & Family support & Competiveness & $\begin{array}{c}\text { Government } \\
\text { Policy }\end{array}$ \\
\hline Risk Taking & $.452^{* *}$ & $.796^{* *}$ & -.192 & $-.333^{* *}$ & $.363^{* *}$ \\
\hline $\begin{array}{l}\text { Inter Locus of } \\
\text { Control }\end{array}$ & $-.350^{* *}$ & $-.682^{* *}$ & .031 & .124 & $-.396^{* *}$ \\
\hline $\begin{array}{l}\text { Tolerance For } \\
\text { Ambiguity }\end{array}$ & $.322^{* *}$ & $.432^{* *}$ & -.111 & -.238 & .194 \\
\hline $\begin{array}{l}\text { Strength And } \\
\text { Energy }\end{array}$ & -.212 & $-.299^{* *}$ & -.169 & -.138 & .010 \\
\hline $\begin{array}{l}\text { Creative And } \\
\text { Innovative }\end{array}$ & .149 & $.388^{* *}$ & $-.273^{*}$ & -.247 & .044 \\
\hline Independence & $.413^{* * *}$ & $.688^{* * *}$ & .021 & -.117 & .232 \\
\hline Self Esteem & $.257^{* *}$ & $.495^{* *}$ & .012 & -.210 & .056 \\
\hline Self Confidence & $.472^{* *}$ & $.683^{* *}$ & -.114 & $-.330^{*}$ & $.382^{* *}$ \\
\hline Competitiveness & .154 & .187 & -.041 & -.033 & .011 \\
\hline Pro-activeness & .156 & .183 & -.009 & -.011 & -.023 \\
\hline Self-Achievement & $.425^{* *}$ & $.308^{*}$ & -.042 & -.051 & .187 \\
\hline
\end{tabular}

**. Correlation is significant at the 0.01 level (2-tailed).

*. Correlation is significant at the 0.05 level (2-tailed).

Source: Field survey 2015.

According to the Pearson Correlation analysis in the above table indicates that every aggregate variable has a mutual correlation with a statistical significance. According to the results, the strongest correlation exists between Risk taking propensity and Support services $(\mathrm{r}=$ .796). This represents that women entrepreneurs Risk taking propensity can easily be enhanced through the activities of business support services. Second highest Independence and support services $(\mathrm{r}=.688)$. Followed by Selfconfidence $(\mathrm{r}=.683)$, Internal Locus of Control $(\mathrm{r}=.682)$ and support services. 
Environmental Factors and Women Entrepreneurship

The second hypothesis is a "there is a significant relationship between entrepreneurship development (WED). The dependent variable WED has been measured by women's ability to a start-up business, transform into a profitable business and expand their business. WED measured through entrepreneurial traits. Correlation analysis describes the relationship between the dependent variable and independent variables. Multiple regression analysis is also done to determine the highest influence factor on WED. The following table indicated the coefficient values of independent and dependent variables.

Table 6: Coefficients ${ }^{\mathrm{a}}$

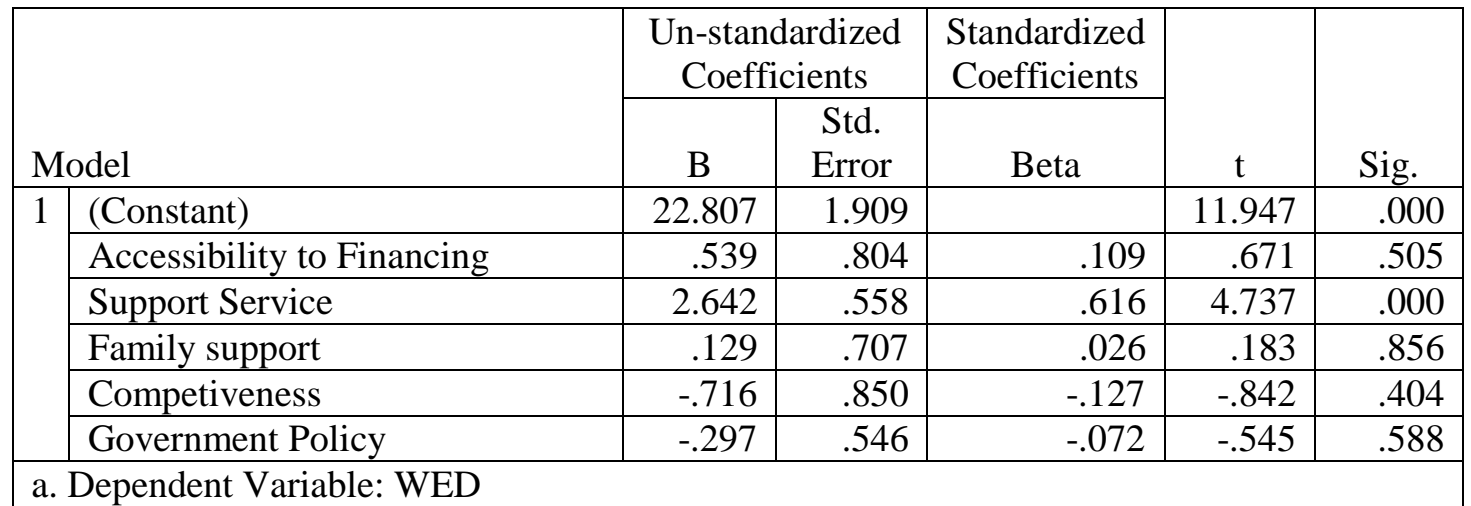

Source: Field survey 2015.

According to the values of the above table, Business support services are significantly correlated towards WED, because it's having highest t-value and beta value; that is $\mathrm{t}=4.737$ and beta $=$
.616. The model (Table 7) used for this research showed that only $51.3 \%$ of the dependent variables was able to explain by the independent variables ( $\mathrm{R} 2=.513$ ). Therefore the model is not strongly fitted.

Table 7: Model Summary ${ }^{\text {b }}$

\begin{tabular}{|c|c|c|c|c|c|}
\hline Model & $\mathrm{R}$ & R Square & $\begin{array}{l}\text { Adjusted R } \\
\text { Square }\end{array}$ & $\begin{array}{l}\text { Std. The error of } \\
\text { the Estimate }\end{array}$ & Durbin-Watson \\
\hline 1 & $.716^{\mathrm{a}}$ & .513 & .467 & 4.04097 & 1.941 \\
\hline
\end{tabular}

a. Predictors: (Constant), Gvt Policy, Family support, Support Service, Competitiveness, Accessibility To Financing b. Dependent Variable: WED

Source: Field survey 2015.

By considering the individual basis, Business support services which have the highest score of $r=.705$ shows (Table 8) and secondly accessibility to financing $(\mathrm{r}=.496) . \quad$ Family support and Competitiveness indicated a negative association of $\mathrm{r}=-.207$ and $\mathrm{r}=-.3565$ respectively. 
Table 8: Correlations between independent variables and Women Entrepreneurship Development

\begin{tabular}{|c|l|r|r|r|r|r|}
\hline \multicolumn{2}{|c|}{} & \multicolumn{1}{|c|}{$\begin{array}{c}\text { Accessibility To } \\
\text { Financing }\end{array}$} & $\begin{array}{l}\text { Support } \\
\text { Service }\end{array}$ & $\begin{array}{c}\text { Family } \\
\text { support }\end{array}$ & $\begin{array}{r}\text { Government } \\
\text { Policy }\end{array}$ \\
\hline WED & $\begin{array}{l}\text { Pearson } \\
\text { Correlation }\end{array}$ & .496 & .705 & -.207 & -.365 & .234 \\
\cline { 2 - 7 }$(1-$ & $\begin{array}{l}\text { Sig. } \\
\text { tailed) }\end{array}$ & .000 & .000 & .058 & .002 & .037 \\
\hline
\end{tabular}

Source: Field survey 2015.

\section{DISCUSSION}

Women Entrepreneurship Development has been studied from the viewpoint of some environmental factors, such as: financial accessibility, business development support services, family support, competitiveness and government policy. Among all these factors business development support services indicated that significant in terms of WED. The study revealed that there is a positive relationship between entrepreneurial traits and demographic variables because most of women entrepreneurs started their business in age between $20-50$ years. This was also consistent with the study of (Ronsdant, 1984), who discovered that most entrepreneurs start their business in the age range of 22 and 55 (Okafor \& Mardi, 2010). This study was showed that the relationship between women entrepreneurial traits and environmental factors. It was indicated even though that there is a relationship between two variables, it is not so strong one. Previous studies such as, (Morris \& Lewis, 1991) (ILO I. L., 2003) (Familoni, 2007) indicated that entrepreneurial traits can be influenced by entrepreneurs environmental either negatively and positively.

\section{CONCLUSION}

According to the results of this study entrepreneurial development linked with the entrepreneurs' psychological traits and subject to environmental factors that affect the particular business. On the other hand, VIDATHA program is fulfilling link between the R\&D institutions and the potential entrepreneurs at the village level. The program has become more popular among technology producers and technology hunters. This program makes the prospective entrepreneurs aware of technologies that are available for commercialization. Also, VIDATHA is trying to promote entrepreneurial culture in the rural community. According to the women entrepreneur's point of view transfer of technologies without financial and marketing support will not make desired outcomes of the programme. Barriers to effective technology transfer have to be overcome. Also, one of the major challenges to be addressed is the dependency of rural community on free social welfare programmes, in order to deliver expected outcomes of VIDATHA. 


\section{REFERENCE}

Annekova, V. (2001). Global Approach to fostering Development of Women Entrepreneurship, FSA Contemporary Issues. IREX.

Bhatt, E. (1991). Women and selfemployment case study of SEWA. Women and development: women in enterprise and profession. New Delhi: Discovery.

Carland, H. J., Boulton, W. F., \& Carland, J. C. (1984). Differencing Entrepreneurs from Small Business Owners: A Conceptualization. Academy of management Review, 9(2), 354-359.

Danie, P. (2004). Free Agent: The Self Employment Experience of Immigrants.

Familoni, O. (2007). Leadership Styles of Great Men. Lagos: Concept Publications.

Heintz, J. (2006). Globalisation, Economic Policy and Employment: Poverty and Gender Implications. Geneva International Labour Office, Employment Policy Unit.

Hisrich, R. D., \& Brush, C. (2006). The Women Entrepreneurship: Self Employment and Occupational Structure in an Industrializing City. Social Science History, 15:67-95.
ILO. (1998). Gender Issues in MicroEnterprise Development: A Briefing Note. The International Small Enterprise Programme (ISEP).

ILO. (2003, July). Small and Medium Enterprise Development. IFPISEED, 3. Globalization and Gender Briefs Series.

Jayaweera, S. (1996). Factors Affecting Women Entrepreneurship in Small and Cottage Industries in Sri Lanka. ILO-SAAT. Ed. Gerry Finnegen.

Weller, e. (1999). Nigeria Agriculture/Micro Enterprise Field Visit. Summary Report designed to assist in the Implementation of the USAID/Nigeria Transition Strategy(S02). 